\title{
O império das medidas provisórias e a proteção do mercado no Brasil em tempos de pandemia
}

\author{
El imperio de las medidas provisionales y la protección del mercado en Brasil en \\ tiempos de pandemia
}

\author{
Tatiana Cardoso SQuefF ${ }^{1}$ \\ Universidad Federal de Uberlândia, Brasil \\ Lúcia Souza D'AQuino ${ }^{2}$ \\ Universidad Federal de la Grande Dourados, Brasil \\ Maria Luiza B. Targa ${ }^{3}$ \\ Universidad Federal de Rio Grande del Sur, Brasil
}

\begin{abstract}
RESUMO Durante a pandemia de Covid-19 e diante da crise por ela gerada, nada mais natural que um governo atue na tentativa de conter não só o alastramento do vírus na sociedade, mas igualmente para mitigar as consequências diretas e indiretas por ele causadas nas mais diversas áreas, com especial atenção àquelas mais vulneráveis. $\mathrm{O}$ caso do Brasil não seria diferente se as medidas arquitetadas no âmbito do Poder Executivo não fossem largamente voltadas para setores e pessoas físicas e jurídicas que não necessariamente deveriam ser "socorridas" da forma como restou estipulado. Em vista disso, esse texto tem como objetivo discutir quatro Medidas Provisórias - MPs 925, 948, 958 e 966 - publicadas pelo Executivo brasileiro voltadas a proteção do mercado em detrimento da defesa do consumidor durante a pandemia, a fim de expor, a partir do método indutivo-dedutivo e de uma análise analítico-descritiva, o seu teor e verificar as suas incongruências, em especial, frente ao texto constitucional. Ao cabo, atento à Constituição de 1988 e à condição por ela reconhecida para a
\end{abstract}

1. Professora permanente da Pós-Graduação em Direito da Universidade Federal de Uberlândia e Professora adjunta na graduação em direito internacional na mesma instituição. Doutora em Direito Internacional pela UFRGS. E-mail: tatiafrcardoso@gmail.com.

2. Professora Substituta da Universidadade Federal da Grande Dourados. Doutora em Direito pela UFRGS. E-mail: luciasdaquino@gmail.com.

3. Doutoranda em Direito pela UFRGS. E-mail: mlbtarga@gmail.com. 
proteção da dignidade humana daquele que consome, conclui-se que o Poder Executivo deveria pugnar pela sua defesa em primeiro lugar mesmo em meio à crise múltipla corrente, o que não é o caso das MPs comentadas, cuja inconstitucionalidade demanda que as mesmas não sejam transformadas em Lei pelo Congresso Brasileiro.

PALAVRAS-CHAVE Medidas provisórias; covid-19; consumidor; Brasil.

RESUMEN Durante la pandemia del Covid-19 y ante la crisis que generó, nada más natural que un gobierno actúe en un intento por contener no solo la propagación del virus en la sociedad, sino también para mitigar las consecuencias directas e indirectas que provoca en las áreas diversas, con especial atención a los más vulnerables. El caso de Brasil no sería diferente si las medidas diseñadas en el ámbito del Poder Ejecutivo no estuvieran dirigidas en gran medida a sectores y personas naturales y jurídicas que no necesariamente deberían ser "rescatadas" en la forma estipulada. Ante esto, este texto tiene como objetivo discutir cuatro Medidas Provisionales - MPs 925, 948, 958 y 966 - publicadas por el Ejecutivo brasileño con el objetivo de proteger el mercado a expensas de la protección al consumidor durante la pandemia, con el fin de exponer, desde el método inductivo-deductivo y análisis analítico-descriptivo, su contenido y verificación de sus inconsistencias, especialmente en relación con el texto constitucional. Al fin y al cabo, atenta a la Constitución de 1988 y la condición que reconoce para la protección de la dignidad humana de quienes consumen, se concluye que el Poder Ejecutivo debe esforzarse por su defensa en primer lugar incluso en medio de la actual crisis múltiple, que este es el caso de los diputados comentados, cuya inconstitucionalidad exige que no sean transformados en ley por el Congreso brasileño.

PALABRAS CLAVE Medidas provisionales; COVID-19; consumidor; Brasil.

\section{Introdução}

A pandemia de SARS-CoV-2, iniciada ainda em dezembro de 2019 na província de Wuhan, China, pegou o mundo totalmente desprevenido ${ }^{4}$. Em função da globalização aprofundada pela qual perpassamos, em uma questão de semanas, o sudeste asiático já enfrentava o alastramento do vírus; e em meados de março, ele já atingia

4. Há evidências de que a administração passada dos Estados Unidos já cogitava uma possibilidade de pandemia, muito embora improvável. $C f$. KNIGHT (2020). 
todos os continentes habitados do globo ${ }^{5}$, motivo pelo qual, inclusive, no dia 11 de março, a Organização Mundial da Saúde já declarava a existência de uma pandemia 6 .

O Brasil teve o seu primeiro caso confirmado no dia 26 de fevereiro ${ }^{7}$ e em 20 de março o governo já declarava a transmissão comunitária em todo o país ${ }^{8}$. Em $1^{\circ}$ de junho de 2020, os casos confirmados somavam 529.405 pessoas, das quais 30.058 faleceram em função da Covid-19, doença causada pela SARS-CoV-2, no Brasil ${ }^{9}$. Logo, mesmo não tendo chegado ainda no pico da doença, o país já estaria ocupando a segunda colocação em número de casos, restando atrás dos Estados Unidos, e a quarta colocação em número de fatalidades, "perdendo" apenas para Estados Unidos, Reino Unido e Itália ${ }^{10}$.

Esses números são alarmantes, especialmente considerando a existência de uma subnotificação crônica no Estado brasileiro tanto de casos, em função da inexistência de uma testagem ampla ${ }^{11}$, como também de mortes ${ }^{12}$, uma vez que diversos pacientes que vieram a óbito por síndrome respiratória aguda no país que não foram testados para a Covid-19, denotando a existência de uma verdadeira crise sanitária - crise essa que não se limita às questões de saúde pública, mas das mais diversas ordens, como a social, a econômica e a política.

Assim sendo, o Estado brasileiro viu-se - e ainda se vê - diante de uma crise múltipla, sem precedentes, a qual demanda uma reação bastante ativa por parte das autoridades públicas na tentativa de conter não só o alastramento do vírus na sociedade, mas também para mitigar as consequências diretas e indiretas por ele causadas nas mais diversas áreas. Nesse escopo, tanto o Poder Legislativo quanto o Poder Executivo brasileiro têm atuado ativamente ${ }^{13}$, aprovando uma série de medidas normativas voltadas para tais fins.

Ocorre que, dentre essas medidas, aquelas arquitetadas no âmbito do Executivo têm gerado uma série de discussões, notadamente, quanto à sua constitucionalidade, vez que voltadas para setores e pessoas físicas e jurídicas que não necessariamente

5. SQUEFF et al (2020a).

6. WORLD HEALTH ORGANIZATION (2020).

7. MONEYTIMES (2020).

8. VALENTE (2020a).

9. G1 (2020a).

10. G1 (2020a).

11. LAGO y TOLEDO (2020); O GLOBO (2020).

12. LOPES (2020).

13. Imperioso salientar que essa tem sido uma tendência do governo de Jair Bolsonaro à frente do Brasil, qual seja, governar por meio da edição de Medidas Provisórias (MPs), as quais, muito embora tenham efeito imediato a partir da sua adoção pelo Executivo e vigorem por 60 dias, prorrogáveis por igual período, devem ser apreciadas pelo Congresso Nacional para a sua conversão em Lei, sob pena de, se não forem votadas até o final deste período, perderem a validade (BRASIL [Constituição Federal], 1988, art. 62). Em 2019, foram editadas 48 MPs (SENADO NOTÍCIAS, 2020). 
deveriam ser "socorridas" da forma como restou estipulado. Em vista disso, esse texto tem como objetivo discutir quatro Medidas Provisórias (MPs) editadas pelo Poder Executivo voltadas à proteção do mercado em detrimento da defesa do consumidor, a fim de expor, a partir do método indutivo-dedutivo e de uma análise analíticodescritiva, o seu teor e verificar as suas incongruências, em especial, frente ao texto constitucional.

Afinal, a Constituição Brasileira de 1988 determina não apenas a dignidade da pessoa humana enquanto um princípio norteador do ordenamento jurídico nacional em seu artigo $1^{\circ}$, inciso III, como também que a defesa do consumidor é, ao mesmo tempo, uma garantia fundamental e um princípio da atividade econômica, estando estes especificamente assinalados nos artigos 50, inciso XXXII, e 170, inciso V, da Carta, os quais deveriam ser observados por todos no país ${ }^{14}$, principalmente pelo Poder Executivo quando da edição de Medidas Provisórias.

Noutros termos, o dever de proteção dos consumidores é um direito humano fundamental ${ }^{15}$ que, em função da sua eficácia vertical, torna-se uma obrigação que deve ser sustentada pelo Estado, incluindo-se aqui todos os seus Poderes, e não por ele(s) violada. É o que explicam Benjamin, Marques e Bessa:

[O direito do consumidor é] um direito fundamental (direito humano de nova geração, social e econômico) a uma prestação protetiva do Estado, a uma atuação positiva do Estado, por todos os seus poderes: Judiciário, Executivo, Legislativo. É um direito subjetivo público geral, não só de proteção contra as atuações do Estado (direito de liberdade e direitos civis, direito fundamental de primeira geração em alemão Abwehrrechte), mas de atuação positiva (protetiva, tutelar, afirmativa, de promoção) do Estado em favor dos consumidores (direito a alguma coisa, direito prestacional, direito econômico e social, direito fundamental de nova geração, em alemão Rechte auf positive Handlungen) - grifos nossos ${ }^{16}$.

14. BRASIL, Constituição Federal de 1988, Arts. 1(3), 5(32) e 170(5). Cf. también: SQUEFF (2018). 15. A sua 'fundamentalidade' advém do "o simples fato de que o ato de consumir consiste em uma prática comum a toda a sociedade mundial e que corresponde, em alguma medida, à própria sobrevivência de todo e qualquer ser humano, sobretudo na realidade contemporânea" DAHINTEN y DAHINTEN (2016) p. 8 [versão eletrônica]). Assim, se "[a] rigor, todas as pessoas são em algum tempo, ou em um dado número de relações jurídicas, consumidoras", notadamente em função desta ação permitir a sobrevivência do ser humano, o 'ser consumidor' - ou o direito de consumo - deve ser considerado um direito humano, pois "revela o reconhecimento jurídico de uma necessidade humana essencial, que é a necessidade do consumo" (MIRAGEM [2002], p. 4 [versão eletrônica]). Cf. también: EFING et al (2011) pp. 207-226.

16. BENJAMIN et al (2010) p. 31. 
Portanto, atento à Constituição e à condição por ela reconhecida para a proteção da dignidade humana daquele que consome, o Poder Executivo deveria pugnar pela sua defesa em primeiro lugar, mesmo em meio à crise múltipla causada pela pandemia de Covid-19, pois é isso que demanda o texto fundamental do Estado brasileiro, não sendo factível a defesa de outros setores e pessoas (no caso, as jurídicas) em detrimento do consumidor, sem que, com isso, incorra-se em uma conduta ilegal, tal como se verifica nas MPs 925, 948, 958 e 966, que são o objeto de análise deste estudo e cuja análise segue nos próximos itens deste texto.

\section{A Medida Provisória n. 925 e a proteção do setor de transporte aéreo}

Dentre os modais de transporte para locomoção de pessoas, sem sombra de dúvidas o rodoviário e o aéreo se destacam como as formas mais utilizadas no Brasil. Segundo os últimos dados coletados pela Agência Nacional de Aviação Civil (ANAC) e pela Agência Nacional de Transportes Terrestres (ANTT), respectivamente, 82,o milhões de pessoas utilizaram do transporte aéreo para se locomover por entre os estados da Federação em 2017, enquanto 38,7 milhões de pessoas utilizaram do transporte rodoviário (interestadual) no mesmo período ${ }^{17}$.

Em termos de quantidade, em 2017 foram mais de 805,4 milhões de voos realizados no âmbito doméstico, com uma taxa de ocupação de $81,5 \%$, enquanto o transporte rodoviário realizou apenas 1,1 milhões viagens, com uma taxa de ocupação de $88,2 \%{ }^{18}$. Esses números denotam a preferência pelo uso do transporte aéreo por parte dos passageiros no Brasil e explicam a importância desse segmento no âmbito nacional, o qual, em 2017, "empregava 838,7 mil pessoas e contribuiu com US $\$ 18,8$ bilhões para o PIB"19.

Em vista disso, com o alastramento da Covid-19 no país seguido dos consequentes (a) fechamento de fronteiras externas brasileiras ${ }^{20}$ e (b) adoção de medidas de distanciamento social por prefeitos e governadores ${ }^{21}$, por certo que as pessoas deixariam de voar, não restando dúvidas de que este seria um dos setores mais afetados pela crise. Se mundialmente a média da capacidade de voos ficou na casa dos $59 \%$ em abril e na América Latina a redução da malha aérea foi de $73 \%$, “[s]egundo a ANAC, a malha

17. BRASIL. Ministério dos Transportes, Portos e Aviação Civil (2018) p. 26.

18. BRASIL. Ministério dos Transportes, Portos e Aviação Civil (2018) pp. 25-26.

19. BOUÇAS (2019).

20. Cf. BRASIL, Portaria Interministerial n. 120 de2020, Portaria Interministerial n. 125 de 2020, Portaria Interministerial n. 126 de 2020, Portaria Interministerial n. 132 de 2020, y Portaria Interministerial n. 133 de 2020.

21. VALENTE (2020b).

22. FAVARO (2020). 
aérea [brasileira] foi reduzida em $92 \%$ no mês de abril. As localidades atendidas pelas [companhias] aéreas no Brasil passaram de 106 para 46, e o número de voos semanais caiu de 14.781 para $1.241^{{ }_{23}}$.

Em termos econômicos, a Associação Internacional de Transportes Aéreos (IATA), estimou que os prejuízos às transportadoras aéreas será de aproximadamente 314 bilhões de dólares em função da pandemia no globo ${ }^{24}$. No Brasil, a estimativa também é de prejuízo: muito embora não haja números individualizados, estima-se que o setor de turismo, o qual inclui os serviços com transporte aéreo, terá uma redução de $38,9 \%$ no faturamento ${ }^{25}$.

Portanto, na tentativa de auxiliar o setor a sobreviver à crise, o Presidente da República expediu, em 18 de março, a MP n. $925^{26}$, que dispõe sobre medidas emergenciais para a aviação civil brasileira em razão da pandemia causada pela Covid-19, segundo assevera o seu artigo $1^{\circ}$, entrando em vigor na data de sua publicação, como preceitua o artigo $4^{\text {o27 }}$. Em relação ao seu artigo $2^{\circ}$, este refere que, nos contratos de concessão de aeroportos firmados pelo Governo Federal, as contribuições fixas (montante a ser pago em decorrência de oferta realizada através de leilão) e variáveis (montante anual resultante da aplicação de alíquota sobre a receita bruta da empresa concessionária do serviço e de suas subsidiárias integrais) que vencerem no ano de 2020 poderão ser pagas até o dia 18 de dezembro de 2020.

$\mathrm{O}$ artigo $3^{\circ}$, porém, atinge diretamente os consumidores. Ele estabelece que, em casos de não prestação do serviço contratado, independentemente do motivo, o prazo para reembolso do valor utilizado para adquirir a passagem aérea será de 12 meses, devendo ser observadas as regras do contrato, logo, incluindo-se quaisquer taxas e

\section{FARIA y YUKARI (2020).}

24. IATA (2020).

25. FGV (2020) p. 11.

26. A Medida Provisória foi convertida na Lei no 14.034, de 05 de agosto de 2020. A redação original do texto da MP sofreu alterações e acréscimos advindas das 109 Emendas feitas no projeto no Congresso, as quais são ainda mais prejudiciais aos passageiros-consumidores, a exemplo da prestação de assistência material a ser concedida ao passageiro em casos de atrasos, cancelamentos e interrupções de voos que foi retirada quando da conversão em Lei; da limitação de utilização dos créditos pelos consumidores em até 18 meses do recebimento do mesmo quando não se sabe nem ao certo quando a pandemia irá terminar; e, em especial, a impossibilidade de concessão de danos morais em decorrência da falha na execução do contrato de transporte, o que atenta diretamente contra a Constituição Brasileira Para análise crítica a respeito da referida Lei, ver: SQUEFF y TARGA (2020b); SQUEFF et al (2020b); ATHENIENSE y TARGA (2020a).

27. BRASIL. Medida Provisória n. 945 de 2020. 
multas ali presentes, mas mantida a assistência material nos termos da regulamentação vigente. $O$ parágrafo $1^{\circ}$, contudo, traz uma outra possibilidade, qual seja, a da opção por parte do passageiro da obtenção de um crédito junto à companhia aérea correspondente ao valor pago pelo bilhete, neste caso, sem a incidência de quaisquer penalidades contratuais, para uso no prazo de 12 meses contados da data de partida do voo originariamente contratado. Ao seu turno, o parágrafo $2^{\circ}$ refere que o referido artigo se aplica aos contratos de transporte aéreo firmados até 31 de dezembro de 2020, não indicando um marco temporal inicial.

Em outros termos, a MP estabelece que, para todos os contratos de serviço de transporte aéreo firmados até o final de 2020 , independentemente da data de contratação, os passageiros possuem duas opções, afastando quaisquer outros prazos e medidas mais benéficas ao consumidor: (a) ou aceitam a conversão do valor pago em um crédito que deve ser utilizado em até 12 meses da data da viagem original, sem quaisquer custos adicionais, presumindo que o serviço estará disponível na sua integralidade nos meses subsequentes ${ }^{28}$ e que os consumidores (e a sociedade) não estarão mais expostos ao vírus; (b) ou optam pelo reembolso do valor pago, o qual será realizado em até 12 meses a contar da data da solicitação do reembolso, deduzidas as penalidades contratuais, que, por vezes, são extremamente abusivas, e sem sequer mencionar eventual incidência de correção monetária e juros legais, tal como deveria suceder à luz da legislação consumerista pátria ${ }^{29}$.

28. Deve-se recordar que as companhias aéreas estão redesenhando as suas rotas internas e internacionais, de modo que os passageiros poderão enfrentar dificuldades em obter a prestação do serviço nas mesmas condições da contratação. Cf. CAULYT (2020); G1(2020b).

29. Opções essas que foram corroboradas pela aprovação, em 13 de maio de 2020, da Resolução n. 557 da ANAC, a qual assinalou que o prazo para reembolso de compra de passagens aéreas será de 12 meses e que somente não serão cobradas as penalidades contratuais se aceito pelo passageiro um crédito para utilização em 12 meses a contar da data do voo original. A única exceção segundo a Resolução (e, logo, aplicável apenas a partir dessa data) seria que o prazo de reembolso não se aplicaria aos pedidos de desistência da passagem realizados no prazo de até $24 \mathrm{~h}$ a contar do recebimento do bilhete elo passageiro. Para esses casos, o reembolso deve ocorrer em até sete dias a contar da solicitação feita pelo passageiro nos termos do art. 29 da Resolução n. 400/2016, ressalvando apenas que a compra da passagem aérea deve ter sido feita com antecedência de até sete dias em relação à data de embarque. 
A Medida, por si só, não poderia ser admitida no ordenamento, pois se sobrepõe à leitura da legislação vigente ${ }^{30}$, que protege o consumidor em razão da sua vulnerabilidade intrínseca nas relações de consumo ${ }^{31}$ e que, ao assim fazer assegurava a dignidade humana do homo economicus ${ }^{32}$ nos termos da Constituição (arts. 1, inc. III, e $5^{\circ}$, inc. XXXII), como também desconsidera a necessidade de conduzir-se a economia brasileira à luz de certos parâmetros, que servem como verdadeiros limitadores do mercado e do próprio capitalismo ${ }^{33}$, dentre os quais está a defesa do consumidor (art. 170, inc. V).

Pior ainda é a questão que envolve a assistência material a ser prestada ao passageiro, "mantida" pelo art. $3^{\circ}$ da MP n. 925, a qual corresponde à prestação de deveres acessórios ao contrato, como a satisfação das necessidades do consumidor pelo tempo de espera durante a prestação do serviço, nos termos do que prevê o art. 27 da

30. Refere-se aqui especificamente ao Código Brasileiro de Aeronáutica que afirma em seu art. 229 que "o passageiro tem direito ao reembolso do valor já pago do bilhete se o transportador vier a cancelar a viagem; e à Resolução n. 400/2016 da ANAC, que refere que o prazo para reembolso será de sete dias a contar da data da solicitação realizada pelo passageiro (artigo 29, caput), bem como que será integral em caso de cancelamento de voo, interrupção do serviço ou preterição de passageiro se solicitado no aeroporto de origem, de escala ou conexão, ou proporcional ao trecho não utilizado, se já iniciado o serviço (art. 30, inc. I e II). Referida Resolução também assinala que o reembolso pode ser convertido em crédito, com a condição que o passageiro assim aceite, sendo possível, inclusive, a utilização de crédito para aquisição de passagem aérea para terceiros (art. 31 e seus parágrafos) - ponto este que, de maneira falha, silencia a MP n. 925.

31. MARQUES y MIRAGEM (2014).

32. Acerca deste, explica Claudia Lima Marques: "Consumo é igualdade. Hoje ser cidadão econômico ativo é aproveitar das benesses do mercado liberal e globalizado como agente ativo e consumidor. Consumo é inclusão na sociedade, nos desejos e benesses do mercado atual. Em outras palavras, consumo é, para as pessoas físicas, a realização plena de sua liberdade e dignidade, no que podemos chamar de verdadeira 'cidadania econômico-social". MARQUES (2012) p. 407.

33. É o que exprime Barroso, ministro do Supremo Tribunal Federal: "A experiência demonstrou, todavia, que o sistema de auto-regulação do mercado nem sempre é eficaz em relação a um conjunto de outros aspectos dos produtos e serviços, como qualidade e segurança, veracidade das informações ao consumidor, vedação de cláusulas abusivas, atendimento pós-consumo etc. Daí a necessidade de uma regulamentação específica de proteção ao consumidor, que veio inscrita inclusive como um direito individual constitucionalizado. Trata-se, aqui, tanto de um princípio de funcionamento da ordem econômica, ao qual está vinculada a iniciativa privada, quanto de um dever do Estado". BARROSO (2001) p. 195. 
Resolução n. 400/2016 da ANAC, e que está intimamente ligada à intimidade ${ }^{34}$ e à honra $^{35}$ do consumidor, e cuja violação configura dano moral, passível de indenização nos termos do art. $5^{\circ}$, inc. X, da Constituição de 1988. Isso porque, ao citar a aplicação da legislação vigente, se esta, por suas determinações, vier a transgredir a citada honra e intimidade, incorrer-se-ia em um ato inconstitucional.

E justamente isso que se observa com a edição da Resolução n. 556, de 13 de maio de 2020, cujo teor modificou a assistência a ser prestada pelas companhias aéreas aos passageiros tal como previa a Resolução n. 400 de 13 de dezembro de 2016, nos termos do quadro comparativo abaixo ${ }^{36}$ :

34. A intimidade corresponde "a porção mais escondida da individualidade da pessoa", que inclui "o conjunto de [...] hábitos", os quais não podem ser expostos publicamente voluntária ou involuntariamente. JORGE E SILVA NETO (2013) item 23.10 [versão eletrônica].

35. A honra aqui refere-se à sua espécie subjetiva, atrelada "ao sentimento que o indivíduo tem sobre si mesmo". JORGE E SILVA NETO (2013) item 23.12 [versão eletrônica].

36. Há outras modificações, como (a) a comunicação ao passageiro sobre alteração programada do horário e itinerário de voo, que da antecedência de 72 horas (art. 12 da Resolução n. 400/2016) passou a ser de 24 horas (art. 2 da Resolução n. 556/2020); (b) a reacomodação em voos de terceiros em caso de alterações programadas da empresa, atraso, cancelamento e interrupção, que era uma obrigação a ser cumprida na primeira oportunidade (art. 28 da Resolução n. 400/2016) que deixou de existir (art. 3, inc. II, da Resolução n. 556/2020); (c) da execução de serviço por outra modalidade de transporte, que se antes deveria ocorrer quando o passageiro compareceu ao aeroporto em decorrência de falha de informação do transportador ou em casos de atraso superior a 4 horas ou de cancelamento e interrupção do serviço (art. 12, $\$ 2^{\circ}$, inc. III, e art. 21 da Resolução n. 400/2016), agora não é mais obrigatório (art. 3, inc. III, da Resolução n. 556/2020); e (d) sobre o prazo para resposta às demandas do consumidor, que antes era de 10 dias (art. 39 da Resolução n. 400/2016) e agora obriga-se o uso da plataforma consumidor.gov.br (art. 4 da Resolução n. 556/2020). 
Tabela 1 - Quadro comparativo entre as Resoluções da ANAC sobre a prestação de assistência material ao passageiro.

\begin{tabular}{|c|c|c|}
\hline & Resolução n. 400/2016 & Resolução n. 556/2020 \\
\hline \begin{tabular}{l} 
ASSISTÊNCIA MATERI- \\
AL EM CASO DE ALTER- \\
AÇÃO PROGRAMADA \\
DE VOO PELO TRANS- \\
PORTADOR; ATRASO, \\
CANCELAMENTO E \\
\multicolumn{2}{c}{ INTERRUPÇÃO }
\end{tabular} & $\begin{array}{l}\text { Art. 27, caput: Em caso } \\
\text { de atraso superior a } 1 \mathrm{~h}, \\
\text { o passageiro tem direito } \\
\text { a facilidades de comuni- } \\
\text { cação; se superior a } 2 \mathrm{~h} \text {, a } \\
\text { alimentação e, se superior } \\
\text { a } 4 \mathrm{~h} \text {, a serviço de hosped- } \\
\text { agem e de traslado de ida } \\
\text { e de volta. }\end{array}$ & $\begin{array}{l}\text { Art. 3, inc. I: Se a situação } \\
\text { decorrer do fechamento } \\
\text { de fronteiras ou aeropor- } \\
\text { tos, não estão as compan- } \\
\text { hias aéreas obrigadas a } \\
\text { prestar assistência mate- } \\
\text { rial }\end{array}$ \\
\hline $\begin{array}{c}\text { FORNECIMENTO } \\
\text { ALIMENTAÇÃO }\end{array}$ & $\begin{array}{l}\text { Art. 27, inc. II: Em caso } \\
\text { de atraso superior a } 2 \mathrm{~h}, \mathrm{o} \\
\text { passageiro tem direito a } \\
\text { refeição ou voucher indi- } \\
\text { vidual. }\end{array}$ & $\begin{array}{l}\text { Art. 3, parágrafo único: } \\
\text { Não há obrigatoriedade } \\
\text { no cumprimento dessa } \\
\text { providência. }\end{array}$ \\
\hline
\end{tabular}

Fonte: elaboração própria.

Nesse passo, para os contratos firmados a partir de 13 de maio, tem-se que, sobre eles, incidirá a Resolução n. 556/2020, tal como prescreve o art. $3^{\circ}$ da MP n. 925, tratando-se de uma violação da própria Constituição quando se caracterizarem as situações de não provimento de comunicação, alimentação, hospedagem e translado ao consumidor, pois violam a sua honra e intimidade na medida em que o deixam em uma condição ainda mais vulnerável do que aquela inerente à sua posição na relação de consumo.

Miragem, sobre o tema, ponderou que tais deveres acessórios ao contrato de transporte aéreo deveriam ser mantidos, sobretudo no caso da pandemia de Covid-19, pois mesmo que os cancelamentos e retardações de voos não sejam fatos plenamente imputáveis ao transportador, isso não os exoneraria de cumpri-los em função "do dever genérico de qualidade do serviço previsto no Código de Defesa do Consumidor, como também de regras específicas do contrato de transporte tomando como obrigação de resultado" ${ }^{37}$. Nesse passo, muito embora não cite a Constituição de maneira direta, o atual Secretário Extraordinário de Enfrentamento ao Coronavírus de Porto Alegre faz alusão a esta na medida em que o surgimento do próprio código consumerista brasileiro tem suas origens no texto constitucional de 1988, no 'Ato das Disposições Constitucionais Transitórias' que, em seu art. 48, determinou a sua criação pelo Congresso em 120 dias da promulgação da Carta. 
Logo, da simples leitura do seu teor, conclui-se que a MP procura beneficiar sobremaneira as companhias aéreas e também as concessionárias dos aeroportos, mitigando os seus gastos para o fim de permitir o seu funcionamento e fluxo de caixa durante a pandemia. Por outro lado, ela acaba por prejudicar demasiadamente os passageiros-consumidores dos serviços de transporte aéreo ${ }^{38}$, que se encontram em uma situação de vulnerabilidade absoluta e agravada, em virtude da pandemia, por si só, que impede muitos brasileiros de pagar as suas despesas básicas, necessárias ao seu sustento e ao de suas famílias ${ }^{39}$.

Outrossim, essa não foi a única Medida Provisória aprovada pelo governo brasileiro diante da pandemia que tende a favorecer os fornecedores em detrimento dos consumidores, sendo a MP n. 948 outro exemplo, conforme se verá a seguir.

\section{A Medida Provisória n. 948 e a proteção ao setor do turismo e cultura às custas da redução dos direitos dos consumidores}

Outra norma emitida pelo Poder Executivo com a finalidade de minimizar os prejuízos dos fornecedores em razão da pandemia é a Medida Provisória n. 948, de 8 de abril de $202 \mathrm{O}^{40}$, que "dispõe sobre o cancelamento de serviços, de reservas e de eventos dos setores de turismo e cultura em razão do estado de calamidade pública (...) e da emergência de saúde pública de importância internacional decorrente do coronavírus (Covid-19)" ${ }^{* 1}$. Assim, em 6 artigos, a citada Medida Provisória definiu a resolução de questões decorrentes de cancelamentos de eventos dos setores de turismo e cultura.

\section{TARGA y SQUEFF (2020a).}

39. MARQUES et al (2020) p. 3 [versão eletrônica].

40. A Medida Provisória foi convertida na Lei no 14.046, de 24 de agosto de 2020. A redação original do texto da MP sofreu alterações e acréscimos decorrentes das 296 Emendas sofridas no Congresso, as quais são ainda mais prejudiciais aos consumidores-turistas, pontualmente pela impossibilidade de obter-se imediatamente o reembolso do valor pago ou ainda pela imposição da realização dos serviços postergados em até 12 meses contados da data de encerramento da situação de calamidade pública, o que não necessariamente será a mesma data em que findará a pandemia no país, de modo que não se atenta aos interesses dos consumidores; não haver isenção de custo adicional quando da remarcação de serviço; a inexistência de um dever de reembolso de valores referentes à serviços de agências de viagens já pagos e, em especial, a caracterização de caso fortuito ou força maior para os casos envolvendo a pandemia, tornando impossível o pleito de danos morais. Para análise crítica a respeito da referida Lei, ver: ATHENIENSE y TARGA (2020b); y SQUEFF et al. (2020b).

41. BRASIL. Medida Provisória n. 948 de 2020. 
$\mathrm{O}$ art. $2^{\circ}$ prevê a $n \tilde{a} o$ obrigatoriedade de reembolso de valores pagos pelo consumidor na contratação de serviços, reservas e eventos, estabelecendo a preferência pela (a) remarcação, (b) disponibilização de crédito "para uso ou abatimento na compra de outros serviços, reservas e eventos, disponíveis nas respectivas empresas" ou (c) por acordo realizado com o consumidor. Assim, o reembolso será a última alternativa, passível de solicitação por parte do consumidor em um prazo de até 90 dias da promulgação da MP (isto é, o7 de julho de 2020) quando nenhuma das outras opções se aplique e cujo adimplemento deve ocorrer em até 12 meses a contar do fim do estado de calamidade pública.

Ademais, especialmente quando a remarcação, $o$ art. $2^{\circ}$ estipula que ela ocorrerá sem a cobrança de taxas ou multas adicionais ao consumidor, devendo, outrossim, ser respeitadas a sazonalidade e os valores originalmente despendidos e o prazo de até 12 meses a contar do fim do estado de calamidade pública para que o serviço seja realizado. Já nos casos de disponibilização de crédito ao consumidor, este também poderá ser utilizado em até 12 meses a contar da data do encerramento do estado de calamidade.

$\mathrm{O}$ art. $3^{\circ}$, por sua vez, determina a aplicabilidade do art. $2^{\circ}$ a prestadores de serviços turísticos e sociedades empresárias a que se refere o art. 21 da lei que institui a Política Nacional de Turismo ${ }^{42}$, além de cinemas, teatros e plataformas digitais de vendas de ingressos pela internet. Já o art. $4^{\circ}$ determina que os artistas já contratados quando da edição da MP que forem impactados por cancelamentos "não terão obrigação de reembolsar imediatamente os valores dos serviços ou cachês, desde que o

42. BRASIL. Lei Federal n. 11.771 de 2008. Art. 21: Consideram-se prestadores de serviços turísticos, para os fins desta Lei, as sociedades empresárias, sociedades simples, os empresários individuais e os serviços sociais autônomos que prestem serviços turísticos remunerados e que exerçam as seguintes atividades econômicas relacionadas à cadeia produtiva do turismo: I - meios de hospedagem; II - agências de turismo; III - transportadoras turísticas; IV - organizadoras de eventos; V - parques temáticos; e VI - acampamentos turísticos. Parágrafo único. Poderão ser cadastradas no Ministério do Turismo, atendidas as condições próprias, as sociedades empresárias que prestem os seguintes serviços: I - restaurantes, cafeterias, bares e similares; II - centros ou locais destinados a convenções e/ou a feiras e a exposições e similares; III - parques temáticos aquáticos e empreendimentos dotados de equipamentos de entretenimento e lazer; IV - marinas e empreendimentos de apoio ao turismo náutico ou à pesca desportiva; V - casas de espetáculos e equipamentos de animação turística; VI - organizadores, promotores e prestadores de serviços de infraestrutura, locação de equipamentos e montadoras de feiras de negócios, exposições e eventos; VII - locadoras de veículos para turistas; e VIII - prestadores de serviços especializados na realização e promoção das diversas modalidades dos segmentos turísticos, inclusive atrações turísticas e empresas de planejamento, bem como a prática de suas atividades. 
evento seja remarcado, no prazo de doze meses, contado da data de encerramento do estado de calamidade pública"; já no caso de não prestação do serviço em tal prazo, devem se restituir os valores recebidos atualizados, no prazo de 12 meses a contar do encerramento do estado de calamidade pública.

$\mathrm{O}$ art. $5^{\circ}$ ressalva que as relações de consumo regidas pela MP caracterizam hipóteses de caso fortuito ou força maior, não ensejando danos morais, multas ou outras penalidades previstas no art. 56 do Código de Defesa do Consumidor (CDC) ${ }^{43}$.

Em que pese sua intenção de proteção de negócios jurídicos durante a pandemia, tendo em vista que a taxa de cancelamento de viagens em março foi superior a $85 \%^{44}$, deixando o setor do turismo especialmente afetado, a MP n. 948 foi alvo de críticas, as quais centram-se especialmente na (1) desconsideração da vulnerabilidade do consumidor quando do ajuste interpartes, e (2) na consideração da pandemia enquanto caso fortuito e força maior, logo, (i) não sendo possível atribuir dano moral ao consumidor lesado e (ii) terminando por criar um salvo-conduto aos prestadores de serviço.

Acerca do primeiro ponto, Falcão ressalta que, apesar das adversidades enfrentadas pelos setores do turismo e cultura, o o reconhecimento da vulnerabilidade do consumidor deveria se manter absoluto, não devendo as medidas tomadas com a finalidade de socorrer um setor da economia se sobrepor à "conservação das garantias e dos direitos básicos do consumidor, em alusão ao que estipula a Constituição tanto no art. $5^{\circ}$, inc. XXXII, quanto no art. 170, inc. V, já citados ${ }^{45}$.

Nesse caso, a convergência (dialogada ${ }^{46}$ ) de interesses é que deveria ser buscada - e não a sobreposição. Acerca disso, Falcão ressalta a importância do princípio da harmonia nas relações de consumo, previsto no art. $4^{\circ}$, III do CDC, compatibilizando

43. BRASIL. Lei Federal n. 8.078 de 1990. Art. 56: As infrações das normas de defesa do consumidor ficam sujeitas, conforme o caso, às seguintes sanções administrativas, sem prejuízo das de natureza civil, penal e das definidas em normas específicas: I - multa; II - apreensão do produto; III - inutilização do produto; IV - cassação do registro do produto junto ao órgão competente; V - proibição de fabricação do produto; VI - suspensão de fornecimento de produtos ou serviço; VII - suspensão temporária de atividade; VIII - revogação de concessão ou permissão de uso; IX - cassação de licença do estabelecimento ou de atividade; $\mathrm{X}$ - interdição, total ou parcial, de estabelecimento, de obra ou de atividade; XI - intervenção administrativa; XII - imposição de contrapropaganda. Parágrafo único. As sanções previstas neste artigo serão aplicadas pela autoridade administrativa, no âmbito de sua atribuição, podendo ser aplicadas cumulativamente, inclusive por medida cautelar, antecedente ou incidente de procedimento administrativo.

44. VILELA (2020).

45. FALCÃO (2020).

46. É o que defende Sophia Vial ao tecer que, "ainda que seja razoável uma flexibilização da forma de devolução de valores pagos, há que se garantir um diálogo entre consumidor e fornecedor”, pois, 
a proteção do consumidor com as necessidades dos fornecedores; afinal, a "balança precisa manter-se no melhor equilíbrio possível entre a adoção de medidas de urgência e a preservação de valores e princípios, sob pena de se condenar o cenário socioeconômico a um colapso irreversível e de consequências deletérias" ${ }^{47}$.

Assim sendo, quando a MP n. 948 determina a possibilidade de composição entre as partes como uma opção para resolver as questões envolvendo o ressarcimento, ela deveria ter igualmente considerado a vulnerabilidade intrínseca dos consumidores na sociedade de consumo, especialmente a informacional, sendo ingênuo pensar que as partes podem resolver impasses sem que o fornecedor se prevaleça da sua condição ${ }^{48}$, especialmente num ambiente pandêmico. Logo, a falta de especificação do tipo de acordo e quais condições poderiam ser acordadas dificulta a verificação de sua adequação à lei e sua caracterização com uma solução justa para ambas as partes ${ }^{49}$ podendo vir a ferir, inclusive, o disposto no art. $5^{\circ}$, inc. XIV, da Constituição, a qual assegura a todos o direito à informação, lido em consonância com o art. $6^{\circ}$, inc. III, do $C D C$, que aponta "a informação $0^{50}$ adequada e clara sobre os diferentes produtos e serviços" enquanto um direito do consumidor ${ }^{51}$.

Já em relação ao segundo ponto, Vital direciona suas críticas ao art. $5^{\circ}$ da MP n. 948, que caracteriza hipótese de força maior ou caso fortuito, isentando o fornecedor do pagamento de indenização por danos morais, além de multas e outras penalidades previstas no CDC. Segundo o autor, em consulta a Pfeiffer, este sustentou que o artigo "é de uma impropriedade completa. Se a possibilidade de dano moral está na Constituição, como você afasta por MP?" Pfeiffer ainda questiona o caso em que a situação causadora de danos morais ocorre não em razão da pandemia, mas do próprio comportamento da empresa, como por exemplo destratar um consumidor que busque ressarcimento. Segundo ele, a interpretação do art. $5^{\circ}$, nesse caso, seria um salvo-conduto que levaria a um prejuízo para o consumidor ${ }^{52}$.

do contrário, se estaria "retirando direitos indenizatórios e fiscalizatórios", o que não é admissível à luz da própria Constituição de 1988. VIAL (2020).

47. FALCÃO (2020).

48. FALCÃO (2020).

49. FALCÃO (2020).

50. BRASIL. Constituição Federal de 1988. Art. 5: [...] XIV - é assegurado a todos o acesso à informação e resguardado o sigilo da fonte, quando necessário ao exercício profissional - grifos nossos.

51. BRASIL. Lei Federal n. 8.079 de 1990.

52. VITAL (2020). 
Delmondes e Mello, por seu turno, entendem que o art. $5^{\circ}$ impõe compulsoriamente uma excludente de ilicitude para os fornecedores, afastando o princípio da reparação integral, previsto tanto no Código Civil quanto no CDC - ambos apoiados no texto Constitucional, art. $5^{\circ}$, inc. $\mathrm{V}$ e $\mathrm{X}^{53}-$, em benefício dos artistas e empresá$\operatorname{rios}^{54}$. Outrossim, os direitos dos consumidores devem ser preservados, não importa a situação. As relações de consumo possuem como fundamento e base a boa-fé e a confiança, devendo despertar no fornecedor "o senso de responsabilidade" 55 e não uma oportunidade de 'sobreviver' em meio à crise, desconsiderando o papel que o consumidor terá no pós-pandemia em relação ao seu negócio, sendo imperioso, portanto, debater-se o "dever de solidariedade para manutenção contratual" ${ }^{66}$ em detrimento do seu rompimento abrupto.

Com isso, percebe-se que as grandes - e acertadas - críticas em relação à medida residem na possibilidade de acordo entre fornecedor e consumidor e no teor do art. $5^{\circ}$ da MP n. 948, que caracteriza caso fortuito e força maior e exclui o dever de indenizar por parte do fornecedor ${ }^{57}$. Nesse sentido, deve-se ressaltar o caráter de ordem pública e interesse social do Direito do Consumidor ${ }^{58}$, cuja defesa, nos termos da Carta de 1988, cabe ao Estado, minando de inconstitucionalidade qualquer ato contrário a essa defesa.

Apesar disso, desconsiderando todas as imposições legais, o Poder Executivo tornou mais uma vez a buscar a preservação pura e simples do mercado em detrimento do cidadão, que, inclusive, está por trás da pessoa jurídica atuante nesse espaço, como ocorreu com a edição da MP n. 958, exposta a seguir.

\footnotetext{
53. BRASIL. Constituição Federal de 1988. Art. 5: [...] V - é assegurado o direito de resposta, proporcional ao agravo, além da indenização por dano material, moral ou à imagem; [...] X - são invioláveis a intimidade, a vida privada, a honra e a imagem das pessoas, assegurado o direito a indenização pelo dano material ou moral decorrente de sua violação - grifos nossos.
}

54. DELMONDES y MELLO (2020).

55. VIAL (2020).

56. VIAL (2020).

57. MUCELIN y d'AQUINO (2020).

58. BRASIL. Lei Federal n. 8.079 de 1990. Art. 1: O presente código estabelece normas de proteção e defesa do consumidor, de ordem pública e interesse social, nos termos dos arts. $5^{\circ}$, inciso XXXII, 170, inciso V, da Constituição Federal e art. 48 de suas Disposições Transitórias. 


\section{A Medida Provisória n. 958 e a promessa de mitigação dos impactos econômi- cos através da facilitação do acesso ao crédito}

A pandemia de SARS-CoV-2, como referido, deflagrou uma série de crises no Brasil: "pelo menos 600 mil micro e pequenas empresas fecharam as portas e 9 milhões de funcionários foram demitidos em razão dos efeitos econômicos da pandemia do novo coronavírus" 59 . Com isso, o endividamento e a inadimplência crescem em ritmo acelerado no país ${ }^{60}$, mesmo com "o auxílio emergencial de $\mathrm{R} \$ 600$ [e] o benefício pago a quem teve jornadas e salários reduzidos" ${ }^{61}$. Essa situação é extremamente perigosa, especialmente para a garantia da própria dignidade humana, pois as pessoas passam a restar desprovidas de alimentos, moradia, saneamento, entre outros direitos essenciais, os quais são imperiosos até mesmo para a luta contra a Covid-19.

Ocorre que as pessoas, nessas situações, tornam-se alvos fáceis para que instituições financeiras ofereçam-nas crédito, cujo pagamento, nas condições que lhes são impostas, provavelmente não será efetivado, conduzindo a um círculo vicioso e pernicioso do qual o consumidor não consegue se desvincular, gerando um aumento dos índices de superendividamento da população ${ }^{62}$. E, ao invés de buscar acelerar as propostas que já estão tramitando no âmbito do Poder Legislativo que oferecem respostas a situações como essa - a exemplo dos Projetos de Lei n. 3.515/2015 ${ }^{63}$ e n. $1.997 / 2020^{64}$ - em prol do consumidor (super)endividado ${ }^{65}$, o Poder Executivo terminou por agir de maneira oposta, facilitando o acesso ao crédito a empresas, na tentativa de mitigar os impactos econômicos decorrentes da pandemia nos negócios.

59. BROTERO (2020).

60. SIQUEIRA (2020).

61. MARTINS (2020).

62. MARQUES (2019) p. 245.

63. BRASIL. Câmara dos Deputados (2020).

64. BRASIL. Projeto de Lei n. 1.997 de 2020. Art. $2^{\circ}$ : Fica estabelecida, em razão do estado de calamidade pública provocado pela pandemia de coronavírus (Covid-19), a moratória, até 12 de dezembro de 2020, das obrigações pecuniárias de consumidores pessoas físicas com vencimento a partir de $1^{\circ}$ de abril de 2020, relativas a contratos vigentes anteriormente a 20 de março de 2020 e mencionados na presente Lei.

65. MARQUES et al (2020); MARQUES y PFEIFFER (2020). 
Trata-se da promulgação da MP n. $958^{66}$, em 24 de abril de $2020^{67}$. No seu primeiro artigo, dispensa as instituições financeiras públicas e suas subsidiárias, até o dia 30 de setembro do corrente ano, da apresentação de diversos documentos nas suas contratações e renegociações de operações de créditos realizadas diretamente ou por agentes financeiros.

A primeira dispensa diz respeito à apresentação de certidões de quitação de entrega de relação anual de empregados, para fins de contratação com o governo dos entes federados ou entidades paraestatais. Flexibiliza, assim, a exigência contida no artigo 362, parágrafo $1^{\circ}$, da Consolidação das Leis do Trabalho ${ }^{68}$.

A MP também dispensa a apresentação de certidão de quitação eleitoral para o fim de obtenção de empréstimos em estabelecimentos de créditos mantidos pelo governo ou de cuja administração este participe, bem como para celebrar contratos com tais entidades. Tal exigência está inserida no art. $7^{\circ}$, parágrafo $1^{\circ}$, inc. IV, do Código Eleitoral ${ }^{69}$. Igualmente, desobriga a apresentação de prova de quitação de tributos federais e certidão negativa de inscrição de dívida ativa da União, disciplinada pelo art. 62 da Lei Orgânica da Procuradoria Geral da Fazenda Nacional ${ }^{70}$.

66. BRASIL. Medida Provisória n. 958 de 2020.

67. No dia 24 de agosto, a referida MP perdeu a eficácia porque, embora tenha sido votada pela Câmara dos Deputados, não foi votada pelo Plenário do Senado Federal. Nesta casa, o prazo para a sua tramitação encerrou-se em 23 de outubro de 2020. Para maiores informações, acessar: https://www. congressonacional.leg.br/materias/medidas-provisorias/-/mpv/141701 y https://www12.senado. leg.br/noticias/materias/2020/08/24/medida-provisoria-que-facilitava-creditos-em-bancos-publicos-perde-a-validade.

68. BRASIL. Decreto-Lei n. 5.452 de 1943. Art. 352\$1: As certidões de quitação farão prova até 30 de setembro do ano seguinte àquele a que se referiram e estarão sujeitas à taxa correspondente a 1/10 (um décimo do salário-mínimo regional. Sem elas nenhum fornecimento ou contrato poderá ser feito com o Governo da União, dos Estados ou Municípios, ou com as instituições paraestatais a eles subordinadas, nem será renovada autorização a empresa estrangeira para funcionar no País.

69. BRASIL. Lei n. 4.737 de 1965. Art. $7 \$ 1^{\circ}$ : Sem a prova de que votou na última eleição, pagou a respectiva multa ou de que se justificou devidamente, não poderá o eleitor: IV - obter empréstimos nas autarquias, sociedades de economia mista, caixas econômicas federais ou estaduais, nos institutos e caixas de previdência social, bem como em qualquer estabelecimento de crédito mantido pelo governo, ou de cuja administração este participe, e com essas entidades celebrar contratos.

70. BRASIL. Decreto-Lei n. 147 de 1967. 
A MP ainda libera a apresentação de Certificado de Regularidade do Fundo de Garantia por Tempo de Serviço (FGTS) para fins de obtenção de favores creditícios, isenções, subsídios, auxílios, outorga ou concessão de serviços e outros benefícios concedidos por órgãos da administração dos entes federados ${ }^{71}$. Da mesma forma, dispensa a apresentação de Certidão Negativa de Débito para as contratações com o Poder Público e para o recebimento de benefícios ou incentivo fiscal ou creditício por ele concedido, exigência imposta pelo art. 47, inc. I, alínea 'a', da Lei que dispõe sobre a organização da Seguridade Social ${ }^{72}$.

A MP também isenta o cumprimento da determinação contida no art. 10 da Lei Federal n. 8.870/1994, que exige a apresentação de Certidão Negativa de Débito para fins de contratação de operações de crédito em instituições financeiras que envolvam recursos públicos, recursos do FGTS, do Fundo de Amparo do Trabalhador e do Fundo Nacional de Desenvolvimento da Educação, e também para fins de liberação de parcelas previstas nesses contratos ${ }^{73}$. Dispensa, ainda, a apresentação de certidão de quitação com o FGTS expedida pela Caixa Econômica Federal para fins de operações de financiamento ou de obtenção de dispensa de juros, multa, correção monetária ou outro benefício com lastro em recursos públicos ou oriundos do FGTS ${ }^{74}$.

71. BRASIL. Lei n. 8.212 de 1991. Art. 27: A apresentação do Certificado de Regularidade do FGTS, fornecido na forma do regulamento, é obrigatória nas seguintes situações: [...] b) obtenção, por parte da União, dos Estados ou dos Municípios, ou por órgãos da Administração federal, estadual ou municipal, direta, indireta ou fundacional, ou indiretamente pela União, pelos Estados ou pelos Municípios, de empréstimos ou financiamentos realizados com lastro em recursos públicos ou oriundos do FGTS perante quaisquer instituições de crédito; c) obtenção de favores creditícios, isenções, subsídios, auxílios, outorga ou concessão de serviços ou quaisquer outros benefícios concedidos por órgão da Administração Federal, Estadual e Municipal, salvo quando destinados a saldar débitos para com o FGTS.

72. BRASIL. Lei Federal n. 8.212 de 1991. Art. 47: É exigida Certidão Negativa de Débito-CND, fornecida pelo órgão competente, nos seguintes casos: I - da empresa: a) na contratação com o Poder Público e no recebimento de benefícios ou incentivo fiscal ou creditício concedido por ele.

73. BRASIL. Lei n. 8.870 de 1994. Art. 10: Sem prejuízo do disposto no art. 47 da Lei n. 8.212, de 1991, é obrigatória a apresentação de Certidão Negativa de Débito (CND) pelas pessoas jurídicas e a elas equiparadas, na contratação de operações de crédito junto a instituições financeiras, que envolvam: I - recursos públicos, inclusive provenientes de fundos constitucionais e de incentivo ao desenvolvimento regional (FNO, FNE, FCO, Finam e Finor); II - recursos do Fundo de Garantia do Tempo de Serviço (FGTS), do Fundo de Amparo do Trabalhador (FAT) e do Fundo Nacional de Desenvolvimento da Educação (FNDE); e $\$ 1^{\circ}$ A exigência instituída no caput aplica-se, igualmente, à liberação de eventuais parcelas previstas no contrato.

74. BRASIL. Lei Federal n. 9.012 de 1995. Art. $1^{\circ}$ : É vedado às instituições de crédito realizar operações de financiamento ou conceder dispensa de juros, de multa ou de correção monetária ou 
Ela também permite com que as empresas deixem de comprovar o recolhimento do Imposto sobre a Propriedade Territorial Rural, exigência imposta pela Lei Federal n. 9.393/1996, para o fim de concessão de incentivos fiscais e de crédito rural ${ }^{75}$ ”. E, por fim, flexibiliza a exigência contida no art. $6^{\circ}$ da Lei Federal n. 10.522/2002 referente à obrigatoriedade de consulta prévia ao Cadastro Informativo de créditos não quitados do setor público federal (Cadin), pelos órgãos e entidades da Administração Pública Federal para a realização de operações de crédito que envolvam a utilização de recursos públicos, a concessão de incentivos fiscais e financeiros e a celebração de convênios, acordos, ajustes ou contratos que envolvam desembolso, a qualquer título, de recursos públicos, e respectivos aditamentos ${ }^{76}$.

Os parágrafos desse primeiro artigo ressalvam, contudo, que tais dispensas não afastam a aplicação do disposto no parágrafo $3^{\circ}$ do art. 195 da Constituição Federal, que veda a contratação com o Poder Público ou recebimento de benefícios ou incentivos fiscais ou creditícios por pessoas jurídicas que estejam em débito com o sistema da seguridade nacional ${ }^{77}$. No mais, assinalam que a verificação dessa exigência se dará por meio de sistema eletrônico disponibilizado pela Secretaria Especial da Receita Federal e pela Procuradoria-Geral da Fazenda Nacional. Outrossim, referem que as instituições financeiras devem encaminhar a tais entidades, trimestralmente, a relação das contratações e renegociações de operações de crédito que envolvam recursos públicos. Por fim, ressalvam que as dispensas acima descritas não se aplicam a operações de crédito realizadas com lastro em recursos públicos ou oriundos do FGTS.

Em seu artigo $2^{\circ}$, disciplina que, até 30 de setembro, está suspensa a vigência dos seguintes dispositivos do Decreto-Lei n. 167/1967, que dispõe sobre títulos de crédito rural: o art. 58, parágrafo $2^{\circ}$, e o art. 76. O primeiro refere que, em havendo vinculação de novos bens em caso de mais de um financiamento, a cédula de crédito rural estará sujeita à averbação e à inscrição no Cartório do Registro de Imóveis. E, o segundo, disciplina que, até o resgate da cédula rural, serão segurados os bens nela descritos e caracterizados ${ }^{78}$.

qualquer outro benefício, com lastro em recursos públicos ou oriundos do Fundo de Garantia do Tempo de Serviço (FGTS), a pessoas jurídicas em débito com o FGTS.

75. BRASIL. Lei Federal n. 9.393 de 1996. Art. 20: A concessão de incentivos fiscais e de crédito rural, em todas as suas modalidades, bem como a constituição das respectivas contrapartidas ou garantias, ficam condicionadas à comprovação do recolhimento do ITR, relativo ao imóvel rural, correspondente aos últimos cinco exercícios, ressalvados os casos em que a exigibilidade do imposto esteja suspensa, ou em curso de cobrança executiva em que tenha sido efetivada a penhora.

76. BRASIL. Lei n. 10.522 de 2002.

77. BRASIL. Constituição Federal de 1988.

78. BRASIL. Decreto-Lei n. 167 de 1967. 
Já o artigo $3^{\circ}$ altera o art. $4^{\circ}$ da Lei Federal n. 6.313/1975 , cuja redação original é a seguinte: "o registro da Cédula de Crédito à Exportação será feito no mesmo livro e observados os requisitos aplicáveis à Cédula Industrial”. A nova redação é: "O registro da Cédula de Crédito à Exportação, cabível quando acordado entre as partes, será feito no mesmo livro, observados os requisitos aplicáveis à Cédula Industrial”.

Por fim, o art. $4^{\circ}$ revoga o inc. III, art. 10, da Lei Federal n. 8.870/1994, que dispõe sobre a obrigatoriedade de apresentação de Certidão Negativa de Débito por pessoas jurídicas na contratação de operações de crédito que envolvam recursos captados através de Caderneta de Poupança ${ }^{80}$, e, ainda, revoga o artigo 1.463 do Código Civil, que contém a seguinte redação: "não se fará o penhor de veículos sem que estejam previamente segurados contra furto, avaria, perecimento e danos causados a tercei$\operatorname{ros}^{\prime \prime 1}$.

Da leitura do seu teor, constata-se que a MP n. 958 tem o objetivo de, efetivamente, facilitar o acesso ao crédito por meio de diversas concessões, vigentes até 30 de setembro de 2020. Ainda, de acordo com o Secretário Especial da Previdência e Trabalho do Ministério da Economia, essa MP tem como objetivo principal ajudar a proteger empregos durante a pandemia ${ }^{82}$. No mais, mesmo que relativize obrigações impostas por lei, determina que as instituições financeiras enviem trimestralmente à Receita Federal e à Procuradoria-Geral da Fazenda Nacional da relação de contratações e renegociações de dívidas que envolvam recursos públicos, indicando os beneficiários, os valores e os prazos envolvidos, o que assegura a fiscalização daquelas entidades sobre tais negociações ${ }^{83}$.

Embora, de fato, a facilitação de crédito possa auxiliar tanto na manutenção de empregos quanto no alívio financeiro das empresas (e dos empresários), permitindo fluxo de caixa e pagamento de despesas imediatas e de salários, é preciso sempre levar em consideração a necessidade de fornecimento de crédito consciente também para a pessoa jurídica. Ou seja, não basta conceder o crédito sob o argumento de que este é necessário para a sobrevivência e a solvência da empresa em decorrência da pandemia; é preciso analisar se a obrigação pode ser efetivamente assumida pela parte contratante e se esta terá condições de futuramente honrá-la, sob pena de o remédio passageiro e imediato se tornar, ele mesmo e a longo prazo, o motivo determinante (a) da ruína da empresa, o que impactaria diretamente o mercado interno, sobretudo em relação aos preços e disponibilidade de bens/serviços, e (b) do próprio Estado, uma

79. BRASIL. Lei Federal n. 6.313 de 1975.

80. BRASIL. Lei Federal n. 8.870 de 1994.

81. BRASIL. Lei Federal n. 10.406 de 2002.

82. ESTADÃO (2020).

83. BRASIL. Agência Senado (2020). 
vez que os valores cedidos partem dos cofres públicos e a desconsideração da personalidade jurídica para fins de recuperação do montante seja bastante complexa ${ }^{84}$.

E da mesma forma que ocorre com as demais Medidas Provisórias que foram editadas ao longo da pandemia, muitas vezes escritas às pressas, sem a análise e cuidado necessários, próprios do Poder Legislativo e do processo legislativo, vê-se que a MP em comento analisa unicamente o momento presente, sem se preocupar, a toda evidência, com o que ocorrerá no futuro e como serão honrados todos esses contratos de crédito e de renegociação que serão concedidos de forma facilitada, sem as cautelas necessárias.

Assim sendo, nos parece que melhor do que expedir essa MP teria sido buscar aprovar os Projetos de Lei que regulamentam o superendividamento das pessoas físicas, trazendo medidas de prevenção e de tratamento para tal, cujas disposições são refletidas, sólidas e têm como exemplo o direito comparado ${ }^{85}$, e que buscam garantir o mínimo existencial para uma vida digna, em alusão ao art. $1^{\circ}$, inc. III, da Carta Política, sem contar o próprio art. $5^{\circ}$, inc. XXXII, uma vez que é dever do Estado defender do consumidor - o qual, no caos dessa MP, pode restar duplamente lesado, como referido acima.

Não só isso, cumpre alertar que se fosse realmente do interesse do Poder Executivo proteger o emprego em função da pandemia de Covid-19, essa MP teria como condão colaborar especialmente com o fornecimento de crédito ao micro e pequeno empreendedor, que têm sido os responsáveis pela criação de novos postos de trabalhos formais no Brasil na última década ${ }^{86}$, e não as grandes empresas que são os grandes beneficiários da MP n. $958^{87}$. Se fosse esse o caso, o Poder Executivo poderia ter, inclusive, se inspirado nos projetos existentes voltados às pessoas físicas, na tentativa de fomentar o crédito consciente, assumido de boa-fé, em detrimento de um crédito ou congênere meramente facilitado, que, futuramente se tornará, sem sombra de dúvidas, outra despesa - quiçá até mesmo para o Estado.

Por isso, diante dessas medidas editadas pelo Executivo brasileiro, imperioso debater a responsabilidade dos agentes públicos em tempos de pandemia, particularmente, a exceção criada nesse campo, com a edição da MP n. 966, debatida no ponto subsequente.

84. Especialmente após a reforma introduzida pela MP n. 881/2019, convertida na Lei Federal n. 13.874 de 2019. Para uma análise, $c f$. PENTEADO y MILITELLO (2019).

85. DEUTSCHER BUNDESTAG (2020).

86. GIORDANO (2019).

87. OLIVEIRA (2020). 


\section{A Medida Provisória n. 966 e a (ir)responsabilidade dos agentes públicos}

Por fim, em 13 de maio de 2020 foi publicada a MP n. $966^{88}$, que trata da responsabilização de agentes públicos por ação e omissão em atos relacionados com a pandemia da Covid-19. Em três artigos, a Medida determina quais são os casos em que os agentes públicos podem ser civil e administrativamente responsabilizados por suas condutas em ações relacionadas à pandemia, "ressignifica[ndo] o conteúdo constitucional sobre a responsabilidade do Estado" ${ }^{89}$, prevista no art. 37, parágrafo $6^{\circ 90}$.

Em seu art. $1^{\circ}$, a MP n. 966 dispõe que os agentes só poderão ser civil e administrativamente responsabilizados "se agirem ou se omitirem com dolo ou erro grosseiro pela prática de atos relacionados, direta ou indiretamente" ${ }^{91}$, com as medidas de enfrentamento da emergência de saúde pública e combate aos efeitos econômicos e sociais decorrentes da pandemia. O parágrafo $1^{\circ}$ prevê que a responsabilidade pela opinião técnica não se estende automaticamente àquele que adotá-la como fundamento de decidir e somente se configura se houver elementos suficientes presentes para que o decisor possa aferir o dolo ou erro grosseiro da opinião ou se houver conluio entre os agentes.

$\mathrm{O}$ art. $2^{\circ}$, por seu turno, define o erro grosseiro como aquele erro manifesto, "evidente e inescusável praticado com culpa grave, caracterizado por ação ou omissão com elevado grau de negligência, imprudência ou imperícia" ${ }^{92}$, o que será aferido, de acordo com o art. $3^{\circ}$, considerando-se os obstáculos e as dificuldades reais do agente público; a complexidade da matéria e das atribuições exercidas pelo agente público; a circunstância de incompletude de informações na situação de urgência ou emergência; as circunstâncias práticas que houverem imposto, limitado ou condicionado a ação ou a omissão do agente público; e o contexto de incerteza acerca das medidas mais adequadas para enfrentamento da pandemia da Covid-19 e das suas consequências, inclusive as econômicas.

\footnotetext{
88. Referida MP, atualmente, perdeu a validade a partir do dia 10 de setembro porquanto não chegou a ser votada no Congresso Nacional. Para maiores informações, acessar: https://www12. senado.leg.br/noticias/materias/2020/09/11/mp-que-impede-responsabilizacao-de-agente-publico-na-pandemia-perde-validade.

89. VALENTE (2020c).

90. BRASIL. Constituição Federal de 1988. Art. 37: [...] $\$ 6^{\circ}$ : As pessoas jurídicas de direito público e as de direito privado prestadoras de serviços públicos responderão pelos danos que seus agentes, nessa qualidade, causarem a terceiros, assegurado o direito de regresso contra o responsável nos casos de dolo ou culpa.
}

91. BRASIL. Medida Provisória 966 de 2020.

92. BRASIL. Medida Provisória 966 de 2020. 
A Medida não foi bem recebida, pois, "na prática, o que ela faz é blindar a União de questionamentos futuros por falta de informações sobre a pandemia" ${ }^{93}$. Logo após sua publicação, seis ações diretas de inconstitucionalidade foram ajuizadas, pela Rede Sustentabilidade (ADI 6421), pelo Cidadania (ADI 6422), pelo Partido Socialismo e Liberdade (ADI 6424), pelo Partido Comunista do Brasil (ADI 6425), pela Associação Brasileira de Imprensa (ADI 6427), pelo Partido Democrático Trabalhista (ADI 6428) e pelo Partido Verde (ADI 6431), que afirmaram preocupação "com os critérios de "blindagem" contidos na norma, que poderiam implicar a anistia ou o salvo-conduto a toda e qualquer atuação estatal desprovida de dolo ou erro grosseiro." ${ }^{94}$

Em 21 de maio foi julgado o pedido liminar das ações e proferida decisão no sentido de deferir a antecipação de tutela para:

a) conferir interpretação conforme à Constituição ao art. $2^{\circ}$ da MP 966/2020, no sentido de estabelecer que, na caracterização de erro grosseiro, deve-se levar em consideração a observância, pelas autoridades:

(i) de standards, normas e critérios científicos e técnicos, com especial destaque para as orientações da Organização Mundial de Saúde; bem como

(ii) dos princípios constitucionais da precaução e da prevenção; e

b) conferir, ainda, interpretação conforme à Constituição ao art. $1^{\circ}$ da MP 966/2020, para explicitar que, para os fins de tal dispositivo, a autoridade à qual compete a decisão deve exigir que a opinião técnica trate expressamente:

(i) das normas e critérios científicos e técnicos aplicáveis à matéria, tal como estabelecidos por organizações e entidades médicas e sanitárias, reconhecidas nacional e internacionalmente;

(ii) da observância dos princípios constitucionais da precaução e da prevenção. Foram firmadas as seguintes teses:

"1. Configura erro grosseiro o ato administrativo que ensejar violação ao direito à vida, à saúde, ao meio ambiente equilibrado ou impactos adversos à economia, por inobservância:

(i) de normas e critérios científicos e técnicos; ou

(ii) dos princípios constitucionais da precaução e da prevenção.

2. A autoridade a quem compete decidir deve exigir que as opiniões técnicas em que baseará sua decisão tratem expressamente:

93. VALENTE (2020c).

94. SUPREMO TRIBUNAL FEDERAL (2020). 
(i) das normas e critérios científicos e técnicos aplicáveis à matéria, tal como estabelecidos por organizações e entidades internacional e nacionalmente reconhecidas; e

(ii) da observância dos princípios constitucionais da precaução e da prevenção, sob pena de se tornarem corresponsáveis por eventuais violações a direitos".95

O Ministério Público do Estado de São Paulo, por sua vez, manifestou repúdio à MP n. 966, tecendo que a mesma "subverte alguns princípios basilares da Lei da Improbidade Administrativa", ressaltando que a probidade administrativa não é um favor que se presta à comunidade; pelo contrário, trata-se de um dever do homem público, o que torna a referida Medida "um desserviço ao país" ${ }^{96}$.

A doutrina também se manifestou. De início, cumpre salientar a posição de Azevedo, para quem a MP n. 966 é inconstitucional exatamente por interferir no texto da Carta Política de maneira a tentar tornar parte dela - a culpa 'lato sensu' do agente - inaplicável e fazer com que a atribuição da responsabilidade seja largamente subjetiva, uma vez que não seria possível atribuir a 'culpa grave' a partir da observância de critérios previamente bem estabelecidos, revelando, assim, uma concepção ditatorial de Estado ${ }^{97}$.

Inclusive, essa é a conclusão do Ministro Gilmar Mendes, juiz vogal da ação julgada em 21 de maio acima comentada. Apesar de o Ministro ter expressado o entendimento de que a pandemia permite uma flexibilização do regime jurídico e de que "as balizas trazidas [pela MP n. 966] não se distanciam do regime de responsabilidade civil e administrativa dos agentes públicos constitucionalmente vigente mesmo em circunstâncias de normalidade", contido no art. $37 \$ 6^{\circ}$ da Constituição, tendo o legislador ordinário buscado apenas "conferir maior segurança jurídica ao gestor público, preve[ndo] elementares culposas qualificadas, que pudessem trazer especificação normativa da conduta culposa moldada à práxis da gestão pública regulamentada", o que não se poderia permitir sob hipótese alguma ao gestor público é aplicar um "tratamento não deferente às normas técnicas aplicáveis", pois, essa conduta significaria chancelar a possibilidade de o "Presidente da República ou a qualquer outro gestor público a implementação de uma política genocida na gestão da saúde" ${ }^{98}$. Logo, mesmo concordando com os termos desta MP, o Ministro Gilmar Mendes considerou que as aberturas que ela permitiria não poderiam escapar das amarras legais.

95. REDE Sustentabilidade con Presidente da República (2020).

96. MINISTÉRIO PÚBLICO DO ESTADO DE SÃO PAULO (2020).

97. AZEVEDO (2020).

98. REDE Sustentabilidade con Presidente da República (2020). 
De certa maneira, pode-se dizer que o que o Ministro quis dizer é que existem limites técnicos para tal atuação, o que vai ao encontro das críticas de Lucchesi, para quem a tenacidade da linha divisória entre o certo e o errado é preocupante, especialmente quando diariamente são apresentados novos estudos sobre o vírus e sua transmissão, impondo revisão nos protocolos do governo, o que tem gerado uma verdadeira avalanche de normativas direcionadas aos setores público e privado, bem como à população em geral ${ }^{99}$. Para ele, o mais preocupante a respeito da medida não é sua "má técnica jurídica", mas o estabelecimento de um "princípio de irresponsabilidade jurídica" e a impressão, para os gestores, de que "o afrouxamento das medidas de contenção não acarretará responsabilidade (nem mesmo criminal ${ }^{100}$ ), independentemente de isto estar ou não no melhor interesse da saúde pública”, o que traz prejuízos a toda a sociedade ${ }^{101}$.

Bonin, ao seu turno, relembra que o Presidente, em suas recentes manifestações, chamou a pandemia de gripezinha, de histeria, de neurose, falou que a doença não mataria 800 brasileiros e propôs um churrasco no dia em que o número de mortos no Brasil ultrapassou os 10.0oo. Por fim, quando questionado sobre a proliferação da doença, respondeu aos jornalistas com um "e daí?" ${ }^{102}$. Após tais manifestações, houve a publicação da Medida, o que, segundo o autor, seria uma salvaguarda para suas manifestações e atitudes de enfrentamento da pandemia, como a sua dificuldade em manter um Ministro da Saúde (em 16 de abril de 2020 Luiz Henrique Mandetta deixou a pasta e em 15 de maio de 2020 Nelson Teich também deixou o cargo, que está ocupado interinamente pelo General do Exército Eduardo Pazuello), seus passeios “irresponsáveis" durante o período em que as recomendações da Organização Mundial de Saúde (OMS) reforçam a necessidade de isolamento social, sua ausência "na linha de frente da crise nos estados - ele sequer cogitou ver de perto o que acontece há semanas em Manaus ou em Belém - e a omissão do Planalto nas negociações com a China para compra de respiradores e insumos" ${ }^{103}$.

\section{LUCCHESI (2020).}

100. "Em tese, são quatro os crimes possíveis relacionados à Covid-19 listados no Código Penal: Praticar, com o fim de transmitir a outrem moléstia grave de que está contaminado, ato capaz de produzir o contágio (artigo 131); expor a vida ou a saúde de outrem a perigo direto e iminente (artigo 132); causar epidemia, mediante a propagação de germes patogênicos (artigo 267); e infringir determinação do poder público, destinada a impedir introdução ou propagação de doença contagiosa (artigo 268)". VITAL y ROVER (2020). Foram ajuizadas no Supremo Tribunal Federal seis ações contra Jair Bolsonaro sobre o tema; as seis foram arquivadas. Acerca disso, $c f$. ROVER (2020) y VEJA (2020).

101. LUCCHESI (2020).

102. BONIN (2020).

103. BONIN (2020). 
Tais fatos, aos quais acrescentamos a edição de inúmeras Medidas Provisórias inconstitucionais como aquelas abordadas ao longo deste texto (em que pese haja a necessidade de as mesmas serem assim declaradas pelo Supremo Tribunal Federal para que a responsabilidade civil por ato legislativo atípico se efetive $\left.{ }^{104}\right)$, em razão da MP n. 966, não seriam possíveis de responsabilização do Presidente da República, uma vez que, segundo Bonin, ela cria "outra narrativa para o presidente continuar fugindo do assunto realmente importante", sendo uma "tentativa desesperada do Presidente de escapar do buraco que ele mesmo cavou com esmero nessa crise"105.

Assim sendo, o que se percebe da leitura do texto da norma é um afunilamento da previsão contida no art. 28 da Lei de Introdução às Normas do Direito Brasileiro $^{106}$, que trata da responsabilização pessoal do agente público por suas decisões ou opiniões técnicas em caso de dolo ou erro grosseiro. Ao afirmar que tal responsabilização somente ocorrerá nos casos previstos na Medida e que o erro grosseiro ou culpa grave serão caracterizados levando em consideração as incertezas a respeito da pandemia e de seus efeitos, tem-se a impressão de que diversas atitudes altamente questionáveis, desde a edição destas MPs em apreço a tantas outras ações como a desconsideração das determinações da OMS e a indicação de certos medicamentos, restariam blindadas de eventual responsabilização, o que fatalmente prejudicará a população mais vulnerável.

\section{Considerações finais}

No presente momento, em que o Brasil se encontra em meio a uma crise múltipla provocada pela pandemia de SARS-CoV-2, muito se tem ressaltado a polaridade entre defesa do consumidor ou da economia, o que não deveria ser a pauta para o momento. Em tempos pandêmicos, as relações de consumo deveriam ser ainda mais protegidas, vez que o consumidor não apenas representa o ser humano realizando uma conduta que lhe é vital, especialmente ao considerar o consumo enquanto atividade essencial para atingir-se o mínimo existencial, mas ele também é "uma das principais molas propulsoras da economia"107.

Logo, ao deixar de proteger o consumidor para proteger o fornecedor, o Estado corre o risco de, finda a pandemia, estar em uma situação tal que não haja consumo suficiente para manter a economia do país ativa, mergulhando em uma recessão muito mais difícil de conter. Por isso, muito embora seja necessário a edição de medidas

104. ESTEVES (2003) p. 186.

105. BONIN (2020).

106. BRASIL. Decreto n. 4.657 de 1942. Art. 28: O agente público responderá pessoalmente por suas decisões ou opiniões técnicas em caso de dolo ou erro grosseiro.

107. FALCÃO (2020). 
que tenham como fito contornar os efeitos da pandemia nas relações socioeconômicas do Estado brasileiro, o Poder Executivo não poderia ter esses dois polos enquanto antagônicos e avulsos, que permitiriam a proteção de um em detrimento do outro, tal como fez ao editar as MPs n. 925, 948 e 958.

Afinal, tais Medidas tiveram como principal enfoque a proteção ao mercado e à economia, através de ações que buscam mitigar os prejuízos enfrentados pelos fornecedores em razão da crise/pandemia. E justamente por essa razão é que essas Medidas vão diametralmente de encontro aos interesses fundamentais dos consumidores e ao próprio texto constitucional, o qual não só prescreve enquanto dever do Estado a proteção destes vulneráveis nas relações de consumo, como também determina que a sua defesa deveria ser balizadora das atividades econômicas conduzidas no Estado.

Assim, defende-se que as MPs não sejam convertidas em Lei Federal, cabendo ao Poder Legislativo assegurar que isso não ocorra. Até mesmo porque a defesa dos consumidores também é um dever para os legisladores, tal como também seria ao Poder Executivo, em que pese este esteja desconsiderando essa sua obrigação e muito provavelmente não seja nem punido por isso, igualmente em função de um ato próprio - a MP n. 966.

Esse fato faz relembrar, tal como fez Marques Neto, do 'Ensaio Sobre a Cegueira', de José Saramago, quando exprime que uma epidemia impõe uma nova regra, cujo conteúdo não deveria permitir "nem o justiçamento do administrador de boa-fé, nem a proliferação do vírus da incúria administrativa"108, logo, exatamente o oposto do que ocorre atualmente no Brasil, onde as novas regras - as Medidas Provisórias aqui analisadas - são eivadas de inconstitucionalidade e nem mesmo isso impede que outras normativas infelizmente surjam e deixem de reproduzir tal quadro, em um claro desprezo para com o a parte vulnerável das relações de consumo, que inevitavelmente sofre sobremaneira com as consequências do atual quadro.

\section{Referências}

ATHENIENSE, Luciana y TARGA, Maria Luiza Baillo (2020a): “Os impactos da Lei 14.034/20 nos direitos dos passageiros-consumidores." Disponible en: <https:// www.conjur.com.br/2020-ago-o9/opiniao-lei-1403420-direitos-passageiros-consumidores $>$. [Fecha de consulta: 03 de noviembre de 2020].

ATHENIENSE, Luciana y TARGA, Maria Luiza Baillo (202ob): "Os impactos da Lei 14.046/20 nos direitos dos consumidores-turistas." Disponible en: <https://www. conjur.com.br/2020-set-o9/atheniense-targa-lei-1404620-consumidores-turistas $>$. [Fecha de consulta: 03 de noviembre de 2020].

108. MARQUES NETO (2020). 
AZEVEDO, Reinaldo (2020a): "MP de Bolsonaro e Guedes sobre vírus é inconstitucional; coisa de ditadores". Disponible en: <https://noticias.uol.com.br/colunas/ reinaldo-azevedo/2020/05/14/mp-de-bolsonaro-e-guedes-sobre-virus-e-inconstitucional-coisa-de-ditadores.htm $>$. [Fecha de consulta: 22 de mayo de 2020].

AZEVEDO, Reinaldo (2020b): "Voto de Barroso sobre MP 966 honra direito, ciência e vida. E sem legislar!” Disponible en: <https://noticias.uol.com.br/colunas/reinaldo-azevedo/2020/o5/21/voto-de-barroso-sobre-mp-966-honra-direito-cienciae-vida-e-sem-legislar.htm $>$. [Fecha de consulta: 21 de mayo de 2020].

BARROSO, Luis Roberto (2001): "A Ordem Econômica Constitucional e os Limites à Atuação Estatal no Controle de Preços". En Revista de Direito Administrativo, Rio de Janeiro, vol. 226, 2001, pp. 187-212.

BENJAMIN, Antônio Herman V., MARQUES, Claudia Lima y BESSA, Leonardo Roscoe. (2010): Manual de Direito do Consumidor. (São Paulo, Editora Revista dos Tribunais).

BONIN, Robson (2020): "Bolsonaro tenta se livrar das consequências de sua atuação na pandemia." Disponible en: <https://veja.abril.com.br/blog/radar/bolsonarotenta-se-livrar-das-consequencias-de-sua-atuacao-na-pandemia/>. $[$ Fecha de consulta: 22 de mayo de 2020 ].

BOUÇAS, Cibelle (2019): “Transporte aéreo no Brasil deve dobrar de tamanho até 2037, estima Iata." Disponible en: <https://valor.globo.com/empresas/noticia/2019/10/o3/transporte-areo-no-brasil-deve-dobrar-de-tamanho-at-2037-estima-iata.ghtml>. [Fecha de consulta: 05 de junio de 2020].

BRASIL. Constituição da República Federativa do Brasil de 1988. Disponible en: <http://www.planalto.gov.br/ccivil_o3/constituicao/constituicao.htm>. [Fecha de consulta: 4 de mayo de 2020$]$.

BRASIL. Agência Nacional da Aviação Civil. Resolução 4oo, de 13 de dezembro de 2016. Disponible en: <https://www.anac.gov.br/assuntos/legislacao/legislacao-1/ resolucoes/resolucoes-2016/resolucao-no-40o-13-12-2016>. [Fecha de consulta: 3 de mayo de 2020].

BRASIL. Agência Senado (2020): "Governo edita mais normas para facilitar o acesso ao crédito durante a pandemia." Disponible en: <https://www12.senado.leg. $\mathrm{br} /$ noticias/materias/2020/o4/27/governo-edita-mais-normas-para-facilitar-oacesso-ao-credito-durante-a-pandemia $>$. [Fecha de consulta: 3 de mayo de 2020].

BRASIL. Decreto-Lei $n .147$, de 1967. 
BRASIL. Decreto-Lei n. 167, de 1967.

BRASIL. Decreto-Lei $n$. 5.452, de 1943.

BRASIL. Lei $n$. 4.657, de 1942.

BRASIL. Lei $n$. 4.737, de 1965.

BRASIL. Lei n. 6.313, de 1975.

BRASIL. Lei $n .7 .565$, de 1986.

BRASIL. Lei n. 8.o36, de 1990.

BRASIL. Lei n. 8.o78, de 1990.

BRASIL. Lei n. 8.212, de 1991.

BRASIL. Lei n. 8.87o, de 1994.

BRASIL. Lei n. 9.012, de 1995.

BRASIL. Lei n. 9.393, de 1996.

BRASIL. Lei $n$. 10.406, de 2002.

BRASIL. Lei n. 10.522, de 2002.

BRASIL. Medida Provisória n. 948, de 2020.

BRASIL. Medida Provisória n. 958, de 2020.

BRASIL. Ministério dos Transportes, Portos e Aviação Civil (2018): “Anuário Estatístico de Transportes: 2010-2017." Disponible en: <https://www.infraestrutura.gov. br/images/BIT_TESTE/Publicaçoes/anuario_estatistico_transportes_2010_2017. pdf $>$. [Fecha de consulta: o5 de junio de 2020].

BRASIL. Portaria Interministerial n. 120, de 2020.

BRASIL. Portaria n. 125, de 2020.

BRASIL. Portaria $n .126$, de 2020.

BRASIL. Portaria n. 132, de 2020.

BRASIL. Portaria n. 133, de 2020.

BROTERO, Mathias (2020): "Mais de 600 mil pequenas empresas fecharam as portas com coronavirus." Disponible en: <https://www.cnnbrasil.com.br/business/2020/o4/o9/mais-de-6oo-mil-pequenas-empresas-fecharam-as-portascom-coronavirus $>$. [Fecha de consulta: 05 de junio de 2020]. 
CÂMARA DOS DEPUTADOS. Projeto de Lei $n$. 3.515/2015. Disponible en: <https:// www.camara.leg.br>. [Fecha de consulta: 22 de mayo de 2020].

CAULYT, Fernando (2020): “Companhias aéreas que voam para o Brasil em meio à pandemia." Disponible en: <https://p.dw.com/p/3aSRm>. [Fecha de consulta: 4 de mayo de 2020].

DAHINTEN, Augusto Franke y DAHINTEN, Bernardo Franke (2016): "Direito do Consumidor como Direito Fundamental e o Ensino Superior". En Revista de Direito do Consumidor, São Paulo, vol. 106.

DELMONDES, João Paulo Sales y MELLO, Lucas Nasser de. "Coronavírus e a MP 948/2o dos eventos e turismo: Um socorro para os artistas e empresários em tempos de pandemia." Disponible en: <https://www.migalhas.com.br/depeso/324569/ coronavirus-e-a-mp-948-20-dos-eventos-e-turismo-um-socorro-para-os-artistas-e-empresarios-em-tempos-de-pandemia $>$. [Fecha de consulta: 1 de mayo de 2020].

DEUTSCHER BUNDESTAG (2020): "Entwurf eines Gesetzes zur Abmilderung der Folgen der COVID-19-Pandemie im Zivil-, Insolvenz- und Strafverfahrensrecht". Disponible en: <https://dipbt.bundestag.de/doc/btd/19/181/1918110.pdf >. [Fecha de consulta: 3 de mayo de 2020].

EFING, Antônio Carlos, GIBRAN, Fernanda Mara y BLAUTH, Flávia N. Lazzari. (2011): "A proteção jurídica do consumidor enquanto direito fundamental e sua efetividade diante de empecilhos jurisprudenciais". En Revista Brasileira de Direitos Fundamentais E Justiça, vol. 5, n. 17.

ESTADÃO conteúdo (2020): "MP 958 ajuda a proteger empregos e outras medidas virão, diz Bruno Bianco.” Disponible en: <https://www.istoedinheiro.com.br/mp958-ajuda-a-proteger-empregos-e-outras-medidas-virao-diz-bruno-bianco/>. [Fecha de consulta: 3 de mayo de 2020].

ESTEVES, Júlio César dos Santos (2003): Responsabilidade civil do Estado por ato legislativo (Belo Horizonte, Del Rey).

FALCÃO, Rebeca de Queiroga (2020): “MP n. 948/202o e os efeitos da Covid-19 para o consumidor." Disponible en: <https://www.conjur.com.br/2020-abr-22/rebecafalcao-mp-948-efeitos-consumidor $>$. [Fecha de consulta: 22 de mayo de 2020].

FARIA, Flávia y YUKARI, Diana (2020): "Coronavírus provoca redução de 9o\% dos voos no Brasil, mais que média global". Disponible en: <https://www1.folha.uol. com.br/mercado/2020/o4/coronavirus-provoca-reducao-de-9o-dos-voos-nobrasil-mais-que-media-global.shtml>. [Fecha de consulta: o1 de Junio de 2020]. 
FAVARO, Cristian (2020): "Capacidade global do setor aéreo cai 59\%; queda na América Latina supera a média." Disponible en: <https://economia.uol.com.br/ noticias/estadao-conteudo/2020/o4/17/capacidade-global-do-setor-aereo-cai59-queda-na-america-latina-supera-a-media.htm >. [Fecha de consulta: o5 de Junio de 2020].

FGV (2020): “Impacto Econômico do Covid-19: propostas para o turismo brasileiro”. Disponible en: <https://fgvprojetos.fgv.br/sites/fgvprojetos.fgv.br/files/o1. covid19_impactoeconomico_vo9_compressed_1.pdf $>$. [Fecha de consulta: 02 de Junio de 2020].

G1 (2020a): "Casos de coronavírus e número de mortes no Brasil em $1^{\circ}$ de junho". Disponible en: <https://g1.globo.com/bemestar/coronavirus/noticia/2020/o6/o1/ casos-de-coronavirus-e-numero-de-mortes-no-brasil-em-10-de-junho.ghtml>. Fecha de consulta: o1 de Junio de 2020].

G1 (2020b): "GOL anuncia readequação da malha aérea a partir de maio." Disponible en: <https:/g1.globo.com/economia/noticia/2020/o4/22/gol-anuncia-readequacao-da-malha-aerea.ghtml $>$. [Fecha de consulta: 4 de mayo de 2020].

GIORDANO, Denise (2019): "Dados mostram a importância das micro e pequenas empresas para a economia do Brasil". Disponible en: <https://www.consolidesuamarca.com.br/blog/importancia-micro-pequenas-empresas $>$. [Fecha de Consulta en: 06 de junio de 2020].

IATA (2020): "IATA Reminds Governments in Latin America and Caribbean on Urgency of Relief to the Airline Industry in Face of COVID-19 Crisis." Disponible en: <https://www.iata.org/en/pressroom/pr/2020-04-17-01/>. [Fecha de consulta: 3 de mayo de 2020].

JORGE E SILVA NETO, Manoel (2013): “Curso de Direito Constitucional”. (São Paulo, Saraiva, 8. ed.).

KNIGHT, Victoria (2020): "Fact-check: Did Obama leave no pandemic plan for Trump?” Disponible en: <https://www.statesman.com/news/20200518/factcheck-did-obama-leave-no-pandemic-plan-for-trump $>$. [Fecha de consulta: 24 de mayo de 2020].

LAGO, Cecília do y TOLEDO, Luiz Fernando (2020): "Mesmo com subnotificação crônica, Brasil tem $2^{a}$ maior velocidade de infecção." Disponible en: <https://www. cnnbrasil.com.br/saude/2020/04/30/mesmo-com-subnotificacao-cronica-brasiltem-2-maior-velocidade-de-infeccao $>$. [Fecha de consulta: o1 de junio de 2020]. 
LOPES, Nathan (2020): "Mortes por síndrome respiratória no Brasil aumentam 20 vezes na pandemia." Disponible en: <https://noticias.uol.com.br/saude/ultimasnoticias/redacao/2020/o6/04/obitos-srag-brasil-coronavirus.htm $>$. [Fecha de consulta: 04 de junio de 2020].

LUCCHESI, Guilherme Brenner (2020): "Medida Provisória 966 e (in)segurança jurídica." Disponible en: <https://www.conjur.com.br/2020-mai-16/medida-provisoria-966-inseguranca-juridica>. [Fecha de consulta: 22 de mayo de 2020].

MARQUES, Claudia Lima (2019): "Contratos no Código de Defesa do Consumidor" (São Paulo, Revista dos Tribunais, 9. ed).

MARQUES, Claudia Lima (2012): "Consumo como igualdade e inclusão social: a necessidade de uma lei especial para prevenir e tratar o "superendividamento" dos consumidores pessoas físicas". En Revista Jurídica da Presidência, Brasília, vol. 13, n. 101, 2012, pp. 405-424.

MARQUES, Claudia Lima, BERTONCELLO, Káren y LIMA, Clarissa Costa de (2020): "Exceção dilatória para os consumidores frente à força maior da pandemia de Covid-19: pela urgente aprovação do PL 3.515/2015 de atualização do CDC e por uma moratória aos consumidores." En Revista de Direito do Consumidor, São Paulo, n. 129.

MARQUES, Claudia Lima y MIRAGEM, Bruno (2014): O novo direito privado e a proteção dos vulneráveis (São Paulo, Revista dos Tribunais).

MARQUES, Claudia Lima y PFEIFFER, Roberto Castellanos. (2020): "Superendividamento dos consumidores: Vacina é o PL 3.515 de 2015." Disponíble en: <https:// www.conjur.com.br/2020-mai-14/garantias-consumo-superendividamento-consumidores-vacina-pl-3515-2015>. [Fecha de consulta: 06 de junio de 2020].

MARQUES NETO, Floriano de Azevedo (2020): "Análise: É preciso separar compras emergenciais para pandemia de atos de improbidade." Disponible en: $<$ https://politica-estadao-com-br.cdn.ampproject.org/c/s/politica.estadao.com.br/noticias/ geral,analise-e-preciso-separar-compras-emergenciais-para-pandemia-de-atosde-improbidade,70003298581.amp $>$. [Fecha de consulta: 22 de mayo de 2020].

MARTINS, Raphael (2020): "Endividamento se acentua e pode ser um dos legados da crise do coronavírus." Disponible en: <https://g1.globo.com/economia/noticia/2020/o5/o4/endividamento-se-acentua-e-pode-ser-um-dos-legados-da-crise-do-coronavirus.ghtml>. [Fecha de Consulta: 06 de junio de 2020]. 
MELLO, Cecilia (2020): "Os reflexos jurídicos da Medida Provisória que isenta os agentes públicos de responsabilidade." Disponible en: <https://br.lexlatin.com/ portal/opiniao/os-reflexos-juridicos-da-medida-provisoria-que-isenta-os-agentes-publicos-de>. [Fecha de consulta: 21 de mayo de 2020].

MINISTÉRIO PÚBLICO DO ESTADO DE SÃO PAULO (2020): “Nota de repúdio a teor da Medida Provisória 966/2020.” Disponible en: <http://www.mpsp.mp.br/ portal/page/portal/noticias/noticia?id_noticia=22662917\&id_grupo $=118>$. [Fecha de consulta: 21 de mayo de 2020].

MIRAGEM, Bruno (2002): “O Direito do Consumidor como Direito Fundamental: consequências jurídicas de um conceito". En Revista de Direito do Consumidor, São Paulo, vol. 143.

MIRAGEM, Bruno (2020): "Nota relativa à pandemia de Coronavírus e suas repercussões sobre os contratos e a responsabilidade Civil". En Revista dos Tribunais, São Paulo, vol. 1015.

MONEYTIMES (2020): "Coronavírus chega ao Brasil: contraprova confirma $1^{\circ}$ caso na América Latina”. Disponible en: <https://www.moneytimes.com.br/fast/coronavirus-chega-ao-brasil-contraprova-confirma-1-caso-na-america-latina/>. [Fecha de consulta: 08 mayo de 2020].

MUCELIN, Guilherme y D’AQUINO, Lúcia Souza (2020): “O papel do direito do consumidor para o bem-estar da população brasileira e o enfrentamento à pandemia de COVID-19." En Revista de Direito do Consumidor, São Paulo, v. 129.

O GLOBO (2020): "Estudo no RS aponta alto índice de transmissão em casa e aumento de subnotificações de COVID-19 no estado”. Disponíble em: <https://oglobo.globo.com/sociedade/coronavirus/estudo-no-rs-aponta-alto-indice-de-transmissao-em-casa-aumento-de-subnotificacoes-de-covid-19-no-estado-24401767>. [Fecha de consulta: o8 de mayo de 2020].

OLIVEIRA, Mayara (2020): "Covid-19: MP reduz exigências para empresas tomarem empréstimos." Disponible en: <https://www.metropoles.com/brasil/economia-br/ covid-19-mp-reduz-exigencias-para-empresas-tomarem-emprestimos $>$ [Fecha de consulta: o6 de Junio de 2020].

PENTEADO, Luciana G. y MILITELLO, Denny (2019): "Novos desafios para a desconsideração da personalidade jurídica". Disponible en: <https://politica.estadao. com.br/blogs/fausto-macedo/novos-desafios-para-a-desconsideracao-da-personalidade-juridica/>. [Fecha de consulta: o3 de Junio de 2020]. 
REDE Sustentabilidade con Presidente da República (2020): "Supremo Tribunal Federal, 21 de Mayo de 2020 (Ação Direta de Inconstitucionalidade - ADI 6421)". Disponible en: <http://portal.stf.jus.br/processos/detalhe.asp?incidente=5912207>. [Fecha de consulta: 24 de Mayo de 2020].

ROVER, Tadeu (2020): "Arquivada notícia-crime contra Bolsonaro por causar epidemia e desobediência." Disponible en: <https://www.conjur.com.br/2020-abr-09/ arquivada-noticia-crime-bolsonaro-desobediencia $>$. [Fecha de consulta: o7 de junio de 2020].

SENADO NOTÍCIAS (2020): "Primeiro ano de governo teve 48 medidas provisórias editadas Fonte: Agência Senado." Disponible en: <https://www12.senado.leg.br/ noticias/materias/2020/o1/10/primeiro-ano-de-governo-teve-48-medidas-provisorias-editadas $>$. [Fecha de consulta: 25 de mayo de 2020].

SIQUEIRA, Juliana (2020): "Inadimplência e endividamento crescem na Capital em março". Disponible en: <https://diariodocomercio.com.br/exclusivo/inadimplencia-e-endividamento-crescem-na-capital-em-marco/>. [Fecha de Consulta: o6 de junio de 2020].

SQUEFF, Tatiana de A. F. R. Cardoso (2018): "Bases Constitucionais da Defesa dos Consumidores no Brasil: um resgate acerca da criação da legislação consumerista em prol da confirmação de sua posição privilegiada no ordenamento jurídico pátrio”. En Revista de Direito do Consumidor, São Paulo, v. 116.

SQUEFF, Tatiana Cardoso, D’AQUINO, Lúcia Souza y MUCELIN, Guilherme. "Apresentação". En: SQUEFF, Tatiana Cardoso, d'AQUINO, Lúcia Souza y MUCELIN, Guilherme (2020a): O Direito em tempos de Crise: impactos da Covid-19 nas relações sociojurídicas. (Curitiba, CRV, pp. 13-18).

SQUEFF, Tatiana Cardoso, TARGA, Maria Luiza B. y D'AQUINO, Lúcia Souza (2020b): "O resgate do setor de turismo em meio à pandemia de Covid-19: da edição das Medidas Provisórias 925 e 948 e as suas conversões em lei e do consequente desamparo ao consumidor". En Revista dos Tribunais, Thomson Reuters, v. 1022, diciembre de 2020 , en prensa.

SUPREMO TRIBUNAL FEDERAL (2020): "Plenário do STF examinará ações sobre responsabilização de agentes públicos durante a pandemia". Disponible en: <http:// portal.stf.jus.br/noticias/verNoticiaDetalhe.asp? idConteudo=44364.o\&ori $=1>$. [echa de consulta: 21 de mayo de 2020].

TARGA, Maria Luiza Baillo y SQUEFF, Tatiana Cardoso (2020a): “Os direitos dos passageiros-consumidores de transporte aéreo em tempos de pandemia”. En $R e$ vista de Direito do Consumidor, São Paulo, v. 129. 
VALENTE, Jonas (2020a): “Covid-19: governo declara transmissão comunitária em todo o pais". Disponible en: https://agenciabrasil.ebc.com.br/saude/noticia/2020-03/covid-19-governo-declara-transmissao-comunitaria-em-todo-opais $>$. [Fecha de consulta: 30 de mayo de 2020].

VALENTE, Jonas (2020b): “Covid-19: veja como cada estado determina o distanciamento social." Disponible en: <https://agenciabrasil.ebc.com.br/saude/noticia/2020-04/covid-19-veja-como-cada-estado-determina-o-distanciamentosocial $>$. [Fecha de consulta: 24 de Mayo de 2020].

VALENTE, Fernanda (2020c): "Bolsonaro edita MP para tentar se eximir de erros durante epidemia da Covid-19”. Disponible en: <https://www.conjur.com.br/202omai-14/bolsonaro-edita-mp-isentar-erros-durante-epidemia>. [ Fecha de consulta: 06 de Junio de 2020].

VEJA (2020): "PRG arquiva seis representações contra Bolsonaro por condutas na pandemia". Disponible en: <https://veja.abril.com.br/politica/pgr-arquiva-seisdenuncias-contra-bolsonaro-por-causa-do-coronavirus/>. [Fecha de Consulta: o7 de junio de 2020].

VIAL, Sophia Martini (2020): "Verdade e solidariedade em tempos de coronavírus." Disponible en: <https://www.conjur.com.br/2020-abr-17/martini-vial-verdadesolidariedade-epidemia $>$. [Fecha de consulta: 24 de mayo de 2020].

VILELA, Pedro Rafael (2020): "MP regulamenta reembolso de shows, cinemas e pacotes turísticos." Disponible en: <https://agenciabrasil.ebc.com.br/geral/noti$\mathrm{cia} / 2020-04 / \mathrm{mp}$-regulamenta-reembolso-de-shows-cinemas-e-pacotes-turisti$\cos >$. [Fecha de consulta: 1 de mayo de 2020].

VITAL, Danilo (2020): "MP complementa Código do Consumidor, mas peca na técnica, dizem especialistas." Disponible en: <https://www.conjur.com.br/2020-abr-13/ mp-age-complementar-cdc-peca-tecnica-dizem-especialistas $>$. [Fecha de consulta: 24 de mayo de 2020].

VITAL, Danilo y ROVER, Tadeu (2020): "Aplicação do Direito Penal na pandemia é tênue e ineficiente." Disponible en: <https://www.conjur.com.br/2020-abr-11/ aplicacao-direito-penal-pandemia-tenue-ineficiente $>$. [Fecha de Consulta: o7 de junio de 2020].

WORLD HEALTH ORGANIZATION (2020): "WHO Director-General's opening remarks at the media briefing on COVID-19 - 11 March 2020". Disponible en: <https://www.who.int/dg/speeches/detail/who-director-general-s-opening-remarks-at-the-media-briefing-on-covid-19---11-march-2020 >. [Fecha de consulta: 25 de mayo de 2020]. 